\title{
Pengaruh Pinjaman Modal Terhadap Omzet UMKM di Kecamatan Tenayan Raya Kota Pekanbaru
}

\author{
SRI MULYANA \\ Sekolah Tinggi Ilmu Ekonomi Persada Bunda \\ J1. Diponegoro No. 42 Pekanbaru Telp. (0761)23181 \\ E-mail:srimulyana_ewa@ymail.com
}

\begin{abstract}
SMEs is one of the business sectors that many enthused by business actors, because the sector is very prospective to be developed for the better. the development of SMEs is still problematic in terms of capital, business management, information technology, human resources, bureaucracy and product marketing. The method used in this research is quantitative method. Population in this research is Society which already have SMEs in District Tenayan Raya which amounted to 122 people. The type of data used in this study is secondary data is data obtained from the Department of Cooperatives and Small Medium Enterprises Riau Province. The results showed that capital had an effect of $16 \%$ to turnover variable
\end{abstract}

Keywords: Loan Capital and Omzet

Usaha kecil menengah saat ini memang tengah tumbuh di negara kita. Meski usaha skala kecil, namun perannya sangat berarti dalam upaya turut menopang perekonomian nasional dan menciptakan banyak lapangan kerja baru. Meski seseorang tidak punya ketrampilan sama sekali, mereka bebas memilih peluang bisnis UMKM apa saja yang ingin ditekuni. Di luar soal permodalan, untuk membangun sebuah usaha kecil, seseorang hanya butuh tekad dan keseriusan dalam membangun usahanya.

Di balik besarnya peran usaha mikro bagi perekonomian nasional, salah satu hambatan terbesar dalam mengembangkan usaha mikro adalah sulitnya memperoleh modal awal. Kendala permodalan menjadi yang utama (40.48\%) dari keseluruhan kendala (Kementerian Negara Koperasi dan UKM 2012). Modal merupakan salah satu faktor yang paling berperan dalam usaha mikro dan nantinya akan mempengaruhi omset usaha. Modal awal diperlukan untuk membuka usaha. Besarnya modal awal tergantung pada komoditas usaha. Pemenuhan modal usaha tidak hanya berasal dari uang pribadi pengusaha, namun dari eksternal seperti pinjaman kepada kerabat atau lembaga keuangan seperti bank. Tanpa modal yang cukup, pengusaha tidak bisa memenuhi kebutuhan untuk menjalankan usaha..

Propinsi Riau memiliki iklim bisnis yang tinggi dan juga memiliki perkembangan bisnis umkn. Untuk membangun sebuah usaha kecil, seseorang hanya butuh tekad dan keseriusan dalam membangun usahanya. Namun semua itu tak terlepas dari peranan Pemerintah Provinsi (Pemprov) Riau untuk turut serta menumbuhkembangkan sektor UMKM yang ada di wilayahnya. Berikut merupakan data UMKM yang ada di propinsi Riau

Sebanyak 1.769 pelaku usaha mikro kecil dan menengah di kota Pekanbaru sudah memiliki kartu Izin Usaha mikro-Kecil (IUMK) yang berguna untuk mendapatkan bantuan modal, pembinaan dan pelatihan. Pelaku usaha yang mengurus dan memiliki kartu IUMK banyak berada di Kecamatan Tenayan Raya. Oleh karena itu Kecamatan Tenayan Raya memerlukan bantuan modal untuk dapat meningkatkan omzet UMKM.

Perkembangan suatu usaha tergantung pada tingkat omzet usaha yang 
diperoleh oleh perusahaan. Untuk meningkatkan omzet usaha dibutuhkan modal yang cukup dan dapat menunjang aktivitas usaha yaitu produksi maupun operasional. Omzet usaha yang rendah dapat disebabkan oleh terbatasnya modal usaha yang digunakan untuk menghasilkan suatu produk. Kusumawardani (2014) dalam penelitiannya mengenai faktor-faktor yang mempengaruhi pendapatan usaha, berhasil membuktikan bahwa modal usaha berpengaruh terhadap omzet usaha.

Usaha mikro, kecil, dan menengah (UMKM) memiliki definisi yang bervariasi. Hal tersebut bergantung pada konsep yang digunakan di berbagai negara. Di negara Indonesia, definisi UMKM tercantum dalam pasal 1 UndangUndang Nomor 20 Tahun 2008 tentang Usaha Mikro, Kecil dan Menengah. Berdasarkan undang-undang tersebut definisi UMKM dibagi menjadi tiga bagian diantaranya: a. Usaha Mikro adalah usaha produktif milik orang perorangan dan/atau badan usaha perorangan yang memenuhi kriteria Usaha Mikro sebagaimana diatur dalam UndangUndang ini. b. Usaha Kecil adalah usaha ekonomi produktif yang berdiri sendiri, yang dilakukan oleh orang perorangan atau badan usaha yang bukan merupakan anak perusahaan atau bukan cabang perusahaan yang dimiliki, dikuasai, atau menjadi bagian baik langsung maupun tidak langsung dari usaha menengah atau usaha besar yang memenuhi kriteria Usaha Kecil sebagaimana dimaksud dalam UndangUndang ini. c. Usaha Menengah adalah usaha ekonomi produktif yang berdiri sendiri, yang dilakukan oleh orang perseorangan atau badan usaha yang bukan merupakan anak perusahaan atau cabang perusahaan yang dimiliki, dikuasai, atau menjadi bagian baik langsung maupun tidak langsung dengan

Usaha Kecil atau usaha besar dengan jumlah kekayaan bersih atau hasil penjualan tahunan sebagaimana diatur dalam Undang-Undang ini. Pada kriteria UMKM yang digunakan dalam penelitian adalah jumlah omzet menurut Kementerian
Koperasi dan UKM di Indonesia. Hal tersebut digunakan untuk melihat bagaimana pengaruh antara modal usaha dengan omzet usaha yang diperoleh. Kriteria Usaha Mikro, Kecil, dan Menengah di atur dalam pasal 6 pada UU Nomor 20 Tahun 2008 tentang UMKM.Kriteria Usaha Mikro Kecil dan Menengah Jenis Usaha Omzet Pertahun (rupiah) Usaha Mikro Maksimal 300 Juta Usaha Kecil > 300 Juta - 2.5 Miliar Usaha Menengah > 2.5 Miliar - 50 Miliar Sumber: Kementerian Koperasi dan UMKM 2016

Menurut Kasmir (2016:98) Modal adalah sesuatu yang diperlukan untuk membiayai operasi perusahaan mulai dari berdiri sampai beroperasi. Sedangkan Menurut H. Mulyadi Nitisusastro (2010:238) Modal kerja adalah jumlah kekayaan atau atau aktiva lancer seperti kas atau uang tunai di peti kas dan di bank, pihutang usaha dan persediaan bahan baku bahan pembantu dan barang jadi, ditambah kewajiban dan passive lancer, seperti hutang usaha dan pinjaman jangka pendek.

Menurut Charles W. Gerstenberg dalam Marnis (2008:163-164) "capital is the actual wealt or total asset of the corporation in money, tangible property such as factory, or intangible property such as goodwill. It sd the total investment in the enterprise". Definisi modal tersebut dengan tegas menitik beratkan pengertian modal pada total asset, atau total investment dalam perusahaan.

Setiap perusahaan akan memerlukan modal usaha untuk mendirikan usahanya, menjalankan operasinya dan mengembangkan kegiatannya dari waktu ke waktu. Sebagian modal usaha tersebut datang dari pengusaha atau dari dalam perusahaan dan sebagian lainnya diperoleh dari luar perusahaan. Pada awal pendiriannya, pendanaan kegiatan perusahaan terutama harus bergantung dari modal usaha yang dimiliki oleh para

$$
\text { p.ISSN: } 2407-800 X \quad \text { e.ISSN: 2541-4356 }
$$


pendirinya. Tetapi, setelah perusahaan berkembang, operasinya telah berjalan dengan lancar dan kegiatan perusahaan sudah lebih dikenal, permodalan dari luar untuk menjalankan operasinya menjadi bertambah penting peranannya menurut Sukirno dalam Asep (2016)

Modal usaha bukan hanya uang saja yang dapat dipergunakan untuk proses produksi, tetapi juga terdapat modal yang menunjang proses produksi seperti tanah, mesin, bangunan, peralatan kantor dan lainlain. Kasmir (2016:91-92),kebutuhan modal untuk melakukan usaha terdiri dari dua jenis yaitu:i modal investasi dan modal kerja.Modal investasi digunakan untuk jangka panjang dan berulang-ulang dan biasanya umurnya lebih dari satu tahun.seperti tanah, mesin, bangunan, peralatan kantor dan lain-lain. Modal kerja adalah modal yang digunakan untuk membiayai operasional perusahaan pada saat perusahaan sedang beoperasi.

$$
\text { Motif perusahaaan dalam }
$$

menjalankan usaha adalah Omzet usaha sangat berpengaruh bagi kelangsungan hidup perusahaan, semakin besar omzet usaha yang diperoleh maka semakin besar kemampuan perusahaan untuk membiayai pengeluaran dan kegiatan-kegiatan yang akan dilakukan oleh perusahaan. Kata omzet berarti jumlah, sedang penjualan berarti kegiatan menjual barang yang bertujuan mencari laba atau pendapatan. Jadi omzet penjualan berarti jumlah penghasilan atau laba yang diperoleh dari hasil menjual barang atau jasa Menurut Kusumawardani (2014), semakin besar modal usaha yang digunakan akan diikuti dengan meningkatnya omzet usaha. Asumsinya bahwa dengan modal usaha yang besar, maka akan berpengaruh pada kuantitas dan variasi produk yang dihasilkan.

\section{METODE}

Metode yang digunakan dalam penelitian ini adalah metode kuantitatif. Analisa kuanitatif merupakan analisa yang digunakan terhadap data yang berwujud angka-angka. Kemudian melakukan analisis regresi linier sederhana dengan menggunakan persamaan sebagai berikut: $Y$ $=\mathrm{a}+\mathrm{b} 1 \mathrm{x} 1$

\section{HASIL}

Regresi Linier Sederhana Analisis Regresi Linier Sederhana adalah hubungan secara linier antara satu variabel independen $(\mathrm{X})$ dan variabel dependen $(\mathrm{Y})$. Analisis ini untuk mengetahui arah hubungan antara variabel

Nilai R yang merupakan simbol dari koefisien. Pada tabel diatas nilai adalah 0,40 . Nilai ini dapat diinterpretasikan bahwa hubungan kedua variabel penelitian berada pada kategori cukup. Melalui tabel diatas juga diperoleh nilai $\mathrm{R}$ Square atau koefisien Determinasi (KD) yang menunjukkan seberapa bagus model regresi yang dibentuk oleh interaksi variabel bebas dan variabel terikat. Nilai KD yang diperoleh adalah 16\%. Sehingga dapat ditafsirkan bahwa variabel bebas $\mathrm{X}$ memiliki pengaruh kontribusi sebesar $16 \%$ terhadap variabel $\mathrm{Y}$.

Hasil penghitungan koefisien regresi sederhana diatas memperlihatkan nilai koefisien konstanta adalah sebesar 7.510 koefisien variabel bebas (X) adalah sebesar 0,417. Sehingga diperoleh persamaan regresi $Y=7.510+0,417 \mathrm{X}$. Berdasarkan persamaan diatas diketahui nilai konstantanya sebesar 7.510 secara matematis, nilai konstanta ini menyatakan bahwa pada saat modal 0, maka omzet memiliki nilai 7.510. Selanjutnya nilai positif $(0,417)$ yang terdapat pada koefisien regresi variabel bebas (modal) menggambarkan bahwa arah hubungan antara variabel bebas (modal) dengan variabel terikat (omzet) adalah searah, dimana setiap kenaikan satu satuan variabel modal akan akan menyebabkan kenaikan omzet 0,417 .

UJI T

Perumusan Hipotesis

Ho : Tidak Ada Pengaruh Antara modal Terhadap Omzet UMKM di Kecamatan Tenayan Raya Kota Pekanbaru

p.ISSN: 2407-800X e.ISSN: 2541-4356 
Ha : Ada Pengaruh Antara Modal Terhadap Omzet UMKM di Kecamatan Tenayan Raya Kota Pekanbaru

1. Besarnya nilai $\mathrm{t}$ tabel untuk taraf signifikan $5 \% \mathrm{db}=120(\mathrm{db}=\mathrm{N}-2$ untuk $\mathrm{N}=122$ ) yaitu 1,979

2. Hasil t hitung

Hasil $\mathrm{t}$ hitung diperoleh dengan menggunakan SPSS 17.0 for windows yaitu sebesar 4.779

3. Pengambilan keputusan

Jika $t$ hitung lebih besar dari $t$ tabel maka Ha diterima dan Ho ditolak. Dari hasil perhitungan $\mathrm{t}$ hitung sebesar $4,779 \mathrm{di}$ atas dibandingkan dengan $\mathrm{t}$ tabel $(\mathrm{db}=120)$ yaitu 1,979 taraf signifikan $5 \%$, jadi t hitung $>\mathrm{t}$ tabel maka Ha diterima dan Ho di tolak. Dengan kata lain menolak hipotesis nol (Ho) dan menerima hipotesis alternatif (Ha)

4. Kesimpulan

Sehingga dapat disimpulkan bahwa variabel $\mathrm{X}$ terdapat pengaruh yang signifikan terhadap variabel Y. Dari hasil pengujian hipotesis tersebut terbukti bahwa "Ada Pengaruh Yang Signifikan Antara Modal Terhadap Omzet UMKM di Tenayan Raya Kota Pekanbaru

\section{Koefisien Determinan $\left(\mathrm{R}^{2}\right)$}

Setelah rhitung diketahui sebesar 0,40 maka selanjutnya untuk mengetahui seberapa besar pengaruh variabel $\mathrm{X}$ terhadap variabel $Y$ dengan menggunakan koefisien determinan r2 yang dinyatakan dalam persentase.

Hasilnya sebagai berikut :

$$
\begin{aligned}
\mathrm{R}^{2} & =(0,40) 2 \times 100 \% \\
& =16 \times 100 \% \\
& =16
\end{aligned}
$$

Dari hasil perhitungan di atas maka dapat disimpulkan bahwa ada pengaruh variabel $\mathrm{X}$ terhadap Y sebesar 16\% dan selebihnya yang $84 \%$ dipengaruhi oleh faktor lain.

\section{PEMBAHASAN}

Interpretasi Hasil Penelitian Berdasarkan hasil analisis yang telah diuraikan di atas diperoleh hasil bahwa variabel $(\mathrm{X})$ Modal berpengaruh signifikan terhadap variabel (Y) Omzet UMKM di Kecamatan tenayan Raya Kota Pekanbaru.
Dengan koefisien determinasi sebesar 16 atau $16 \%$ maka berpengaruh positif, artinya jika semakin tinggi Modal maka semakin tinggi pula Omzet UMKM di Kecamatan tenayan Raya Kota Pekanbaru. Sedangkan 84\% merupakan faktor yang mempengaruhi variabel Y dari faktor lain yang tidak diteliti oleh peneliti. Yang tidak diteliti diantaranya faktor lamanya usaha, faktor jumlah produksi, faktor pendidikan Dari hasil analisi uji $\mathrm{t}$ diketetahui bahwa ada pengaruh yang signifikan variabel (X) modal dan variabel (Y) Omzet. Hal ini dibuktikan dengan hasil perhitungan uji t sebesar 4,779 sedangkan pada t tabel adalah 1.979 pada taraf signifikansi 5\% yang berarti bahwa $\mathrm{Ha}$ diterima. Selain itu juga diperoleh persamaan regresi $Y=7.510+0,417 X$. Persamaan tersebut sesuai dengan rumus regresi linier sederhana yaitu $\mathrm{Y}=\mathrm{a}+\mathrm{bX}$, dimana Y merupakan lambang dari variabel terikat, a konstanta, b koefisien regresi untuk variabel bebas (X). sehingga dapat disimpulkan dari hasil uji t, terdapat pengaruh antara variabel $\mathrm{X}$ terhadap Variabel Y, dengan kata lain menerima Ha yaitu : Ada Pengaruh Modal Terhadap Omzet UMKM di Kecamatan Tenayan Raya Kota Pekanbaru, dan menolak Ho, yaitu Tidak Ada Pengaruh Modal Terhadap Omzet UMKM di Kecamatan Tenayan Raya Kota Pekanbaru

Konstanta sebesar 7,510: artinya jika modal $(\mathrm{X})$ nilainya adalah 0 , maka Omzet (Y) nilainya negatif yaitu sebesar 7.510. Koefisien regresi variabel omzet sebesar 0,417: artinya jika modal mengalami kenaikan 1, maka Omzet (Y) akan mengalami peningkatan sebesar 0,417. Koefisien bersifat positif artinya terjadi hubungan posotif antara variabel modal (X) dan Omzet (Y), semakin naik Modal maka semakin meningkat Omzet. Dengan demikian dapat ditarik sebuah kesimpulan bahwa modal cukup mempengaruhi Omzet.

Hasil penelitian ini sejalan dengan apa yang dikatakan Rahman (2017) dalam penelitiannya bahwa modal menjadi salah satu faktor pendorong meningkatnya nilai UMKM.

p.ISSN: 2407-800X e.ISSN: 2541-4356 


\section{SIMPULAN}

Hasil pengujian hipotesisnya menunjukkan bahwa hipotesis alternatif (Ha) yang diajukan dalam penelitian ini diterima, dan menolak hipotesis nol (Ho). Variabel terikat dalam penelitian ini adalah Omzet (Y) sedangkan variabel bebas adalah modal (X). Dari hasil analisi uji t diketetahui bahwa ada pengaruh yang signifikan variabel $(\mathrm{X})$ modal dan variabel (Y) Omzet pada taraf signifikansi alpha 0,05. Berdasarkan uraian tersebut dapat diambil kesimpulan bahwa terdapat pengaruh yang signifikan antara variabel modal $(\mathrm{x})$ dengan variabel Omzet (Y). Artinya semakin tinggi modal maka akan semakin tinngi pula omzet UMKM di Kecamatan Tenayan Raya Kota Pekanbaru

\section{DAFTAR RUJUKAN}

Kasmir. 2016. Kewirausahaan (Edisi Revisi).Jakarta:PT Raja Grafindo Persada

Kotler dan Amstrong. 2008. Prinsip-Prinsip Pemasaran. Jilid 1. Edisi Keduabelas. Jakarta: PT. Indeks.

Manap, Abdul. 2016. Revolusi manajemen Pemasaran.Edisi Pertama.Mitra Wacana Media.Jakarta

Marnis.2008.Pengantar Bisnis. Pekanbaru Panca Abdi Nurhama

Mulyadi Nitisusastro.2010. Kewirausahaan dan Manajemen usaha Kecil. Bandung:Alfabeta

Rahman, F. (2017). Peran Modal Manusia Dan Modal Investasi Terhadap Nilai Produksi Industri Kecil Di Kota Pekanbaru. Jurnal Benefita, 2(1), 19.

Riduwan,2010. Metode \& Teknik Menyusun Tesis, Bandung: Alfabeta

Rochmawati, Miranda. 2015. Analisis Faktor-Faktor Yang Mempengaruhi
Tingkat Pengembalian Kredit Usaha Rakyat (KUR) Mikro(Studi pada PT Bank Rakyat Indonesia (Persero), Tbk Unit Pasirian Cabang Lumajang). Fakultas Ekonomi dan Bisnis : Universitas Brawijaya

Sanusi, Anwar.2011. Metodologi Penelitian Bisnis.Salemba Empat.Jakarta

Suryani,Tatik.2008. Perilaku Konsumen Implikasi pada Strategi Pemasaran.Edisi pertama.Graha Ilmu.Yogyakarta

Tjiptono,Fandi. $2008 . \quad$ Strategi Pemasaran.Edisi Ketiga. Andi Offset.Yogyakarta

Undang-Undang Republik Indonesia Nomor $\quad 20 \quad$ Tahun 2008TentangUsaha Mikro, Kecil, Dan Menengah

http.www.blogspot.co.id/2015/11/pengertia n-omzet-penjualan-menurutahli.html. 